\title{
Penggunaan Google Form pada Pembelajaran Moda Daring untuk Meningkatkan Hasil Belajar Siswa pada Mata Pelajaran Fisika Materi Teori Relativitas Khusus di SMAN 4 Kota Bima Kelas XII MIPA 1 Semester Ganjil Tahun pelajaran 2020/2021
}

\author{
Sutarno \\ SMA Negeri 4 Kota Bima, Kota Bima, Indonesia \\ *Coresponding Author: sutarnosma4@gmail.com \\ Dikirim: 19-08-2021; Direvisi: 24-10-2021; Diterima: 25-10-2021
}

\begin{abstract}
Abstrak: Refleksi hasil pembelajaran pra-siklus yang telah dilakukan peneliti, motivasi siswa menunjukkan $60 \%$ siswa rendah, $25 \%$ sedang, $15 \%$ tinggi dan $0 \%$ sangat tinggi. Rendahnya motivasi belajar siswa ini berdampak pada rendahnya hasil belajar siswa pra-siklus yakni prestasi belajar siswa yang dicapai siswa rata-rata rendah yakni: 73.00 dengan ketuntasan klasikal $74.00 \%$. Hal ini masih dibawah indikator kinerja yang ditentukan yakni rata-rata $\geq 75.00$ dengan ketuntasan klasikal $\geq 85.00 \%$. Berdasarkan latar belakang masalah tersebut peneliti merumuskan masalah sebagai berikut: bagaimana penggunaan google form pada pembelajaran moda daring untuk meningkatkan hasil belajar siswa pada mata pelajaran Fisika materi teori relativitas khusus di SMAN 4 Kota Bima kelas XII MIPA.1 semester ganjil tahun pelajaran 2020/2021?. Tujuan perbaikan penelitian ini adalah : 1 . Mendeskripsikan penggunaan google form pada pembelajaran moda daring untuk meningkatkan hasil belajar siswa pada mata pelajaran Fisika materi teori relativitas khusus di SMAN 4 Kota Bima kelas XII MIPA.1 semester ganjil tahun pelajaran 2020/2021? 2. Mendeskripsikan dampak penggunaan google form pada pembelajaran moda daring untuk meningkatkan hasil belajar siswa pada mata pelajaran Fisika materi teori relativitas khusus di SMAN 4 Kota Bima kelas XII MIPA.1 semester ganjil tahun pelajaran 2020/2021?. Perbaikan dilaksanakan dalam 2 (dua) siklus. Perbaikan dilaksanakan dalam 2 (dua) siklus. Siklus I dari tanggal 17 Juli 2020 sampai dengan tanggal 24 Juli 2020 dan siklus II dilaksanakan tanggal 10 Agustus 2020 sampai dengan 20 Agustus 2020. Subyek peenelitian adalah siswa SMAN 4 Kota Bima dengan jumlah siswa 30, terdiri dari 14 orang laki-laki dan 16 orang perempuan. Teknik pengumpulan data meliputi pengamatan, dokumen dan tes. Teknik pengumpulan data meliputi pengamatan, dokumen dan tes. Peningkatan hasil belajar siswa ini dapat dibandingkan dari hasil tes pra-perbaikan. Data motivasi belajar siklus I diatas menunjukkan bahwa motivasi belajar siswa kategori tinggi 53,33\%, kategori sedang $26,67 \%$ dan kategori rendah $20 \%$. Motivasi belajar siswa dinyatakan berhasil apabila minimal $75 \%$ siswa motivasi belajar tinggi, dan maksimal $10 \%$ siswa motivasi belajar rendah. Dengan demikian indikator motivasi belajar siklus I (pertama) belum berhasil. Hasil pos tes siklus I diatas menunjukkan bahwa hasil belajar siswa matematika rata-rata 74.00 $(+1.00)$, Prosentase ketuntasan klasikal 78.00\% (+3.80), Prosentase ini masih dibawah indikator kinerja yakni $\geq 85 \%$. Dari sisi prestasi belajar siklus I (pertama) belum berhasil. Data motivasi belajar siklus II diatas menunjukkan bahwa motivasi belajar siswa kategori tinggi 76,67\%, kategori sedang 13,33\% dan kategori rendah 6,67\%. Motivasi belajar siswa dinyatakan berhasil apabila minimal $75 \%$ siswa motivasi belajar tinggi, dan maksimal $10 \%$ siswa motivasi belajar rendah. Dengan demikian indikator motivasi belajar siklus II (kedua) telah berhasil. Hasil pos tes siklus II diatas menunjukkan bahwa hasil belajar siswa matematika rata-rata $80.60(+6.60)$. Prosentase ketuntasan $89.00 \%(+11.00)$. Prosentase ini telah memenuhi indikator kinerja yakni $\geq 85.00 \%$. Dengan demikian pada siklus II ini telah berhasil mencapai indikator yang ditetapkan yakni rata-rata $\geq 75.00$ dan prosentase ketuntasan $\geq 85.00 \%$. Dari sisi prestasi belajar siklus II (kedua) telah berhasil. Peningkatkan
\end{abstract}


prestasi belajar siswa, disebabkan oleh peningkatan aktivitas, interaksi guru dan siswa dalam proses pembelajaran daring (online) berbasis Google Form yang dilaksanakan guru, sesuai dengan nilai kinerja guru. Dengan demikian setelah pelaksanaan perbaikan pembelajaran sampai siklus II, telah mencapai indikator kinerja yang ditetapkan, dan penelitian dianggap telah berhasil.

Kata Kunci: Hasil Belajar; pembelajaran daring berbasis Google Form

Abstract: Reflecting on the results of pre-cycle learning that has been done by researchers, student motivation shows $60 \%$ of students are low, $25 \%$ are moderate, $15 \%$ are high and $0 \%$ are very high. The low learning motivation of these students has an impact on the low learning outcomes of pre-cycle students, namely student achievement achieved by students on an average low, namely: 73.00 with $74.00 \%$ classical completeness. This is still below the specified performance indicator, which is an average of 75.00 with a classical completeness of $85.00 \%$. Based on the background of the problem, the researcher formulates the problem as follows: how is the use of google form in online mode learning to improve student learning outcomes in the Physics subject matter of special relativity theory at SMAN 4 Kota Bima class XII MIPA.1 odd semester of the 2020/2021 school year? . The aims of this research improvement are: 1 . To describe the use of google form in online mode learning to improve student learning outcomes in Physics subjects for special relativity theory at SMAN 4 Kota Bima class XII MIPA.1 odd semester for the 2020/2021 school year?. 2. Describe the impact of using google form on online mode learning to improve student learning outcomes in the Physics subject of special relativity theory at SMAN 4 Kota Bima class XII MIPA.1 odd semester of the 2020/2021 school year?. Repairs are carried out in 2 (two) cycles. Repairs are carried out in 2 (two) cycles. Cycle I was from July 17, 2020 to July 24, 2020 and cycle II was held from August 10, 2020 to August 20, 2020. The research subjects were students of SMAN 4 Kota Bima with a total of 30 students, consisting of 14 boys and 16 students woman. Data collection techniques include observations, documents and tests. Data collection techniques include observations, documents and tests. This improvement in student learning outcomes can be compared from the results of the pre-improvement test. The data of the first cycle of learning motivation above shows that the students' motivation in the high category is $53.33 \%$, the medium category is $26.67 \%$ and the low category is $20 \%$. Students' learning motivation is declared successful if at least $75 \%$ of students have high learning motivation, and a maximum of $10 \%$ of students have low learning motivation. Thus the indicators of learning motivation in the first (first) cycle have not been successful. The results of the post-test cycle I above show that the average student learning outcomes in mathematics are $74.00(+1.00)$, the percentage of classical completeness is $78.00 \%(+3.80)$, this percentage is still below the performance indicator, namely $85 \%$. In terms of learning achievement, the first (first) cycle has not been successful. The data of the second cycle of learning motivation above shows that the students' motivation in the high category is $76.67 \%$, the medium category is $13.33 \%$ and the low category is $6.67 \%$. Students' learning motivation is declared successful if at least $75 \%$ of students have high learning motivation, and a maximum of $10 \%$ of students have low learning motivation. Thus the indicators of learning motivation in cycle II (second) have been successful. The results of the post-test cycle II above show that the average student learning outcomes in mathematics are 80.60 $(+6.60)$. The percentage of completeness is $89.00 \%(+11.00)$. This percentage has met the performance indicator of $85.00 \%$. Thus, in the second cycle, it has succeeded in achieving the specified indicators, namely an average of 75.00 and the percentage of completeness $85.00 \%$. In terms of learning achievement, cycle II (second) has been successful. The increase in student learning achievement is caused by an increase in activities, teacher and student interactions in the Google Form-based online learning process carried out by teachers, according to the teacher's performance value. Thus, after the implementation of 
learning improvements up to cycle II, the performance indicators have been achieved, and the research is considered successful.

Keywords: Learning Outcomes; Google Form-based online learning

\section{PENDAHULUAN}

Pada 31 Desember 2019, WHO China Country Offce melaporkan kasus pneumonia yang tidak diketahui etiologinya di Kota Wuhan, Provinsi Hubei, China. Pada tanggal 7 Januari 2020, China mengidentifkasi pneumonia yang tidak diketahui etiologinya tersebut sebagai jenis baru coronavirus (novel coronavirus). Pada awal tahun $2020 \mathrm{NCP}$ mulai menjadi pendemi global dan menjadi masalah kesehatan di beberapa negara di luar RRC. Berdasarkan World Health Organization (WHO) kasus kluster pneumonia dengan etiologi yang tidak jelas di Kota Wuhan telah menjadi permasalahan kesehatan di seluruh dunia. Penyebaran epidemi ini terus berkembang hingga akhirnya diketahui bahwa penyebab kluster pneumonia ini adalah Novel Coronavirus. Pandemi ini terus berkembang hingga adanya laporan kematian dan kasus-kasus baru di luar China. Pada tanggal 30 Januari 2020, WHO menetapkan COVID-19 sebagai Public Health Emergency of International Concern (PHEIC)/ Kedaruratan Kesehatan Masyarakat Yang Meresahkan Dunia (KKMMD)1. Pada tanggal 12 Februari 2020, WHO resmi menetapkan penyakit novel coronavirus pada manusia ini dengan sebutan Coronavirus Disease (COVID-19). COVID-19 disebabkan oleh SARS-COV2 yang termasuk dalam keluarga besar coronavirus yang sama dengan penyebab SARS pada tahun 2003, hanya berbeda jenis virusnya. Gejalanya mirip dengan SARS, namun angka kematian SARS $(9,6 \%)$ lebih tinggi dibanding COVID-19 (saat ini kurang dari 5\%), walaupun jumlah kasus COVID-19 jauh lebih banyak dibanding SARS. COVID-19 juga memiliki penyebaran yang lebih luas dan cepat ke beberapa negara dibanding SARS (Dr. Safrizal ZA, MSi. 2020) termasuk menyebar di Indonesia.

Setelah merebaknya wabah COVID-19, dunia pendidikan mengalami perubahan yang luar biasa khususnya dalam sistem pembelajaran. Pembelajaran secara konvensional tatap muka langsung dengan peserta didik, selama bertahuntahun bahkan berabad-abad telah berjalan, tiba-tiba pada kondisi tertentu dihentikkan sesuai dengan kondisi covid-19 yang ada di lingkungan sekolah sampai batas waktu tertentu pula. Kondisi ini mendorong pelaku pendidikan, termasuk peneliti untuk berupaya, berinovasi agar proses pembelajaran terus berjalan efektif meskipun dalam kondisi tidak melalui tatap muka konvensional. Pembelajaran merupakan suatu sistem yang kompleks yang keberhasilannya dapat dilihat dari dua aspek yaitu aspek produk dan aspek proses. Keberhasilan pembelajaran dilihat dari sisi produk adalah keberhasilan siswa mengenai hasil yang diperoleh dengan mengabaikan proses pembelajaran. (Sanjaya, 2011).

Untuk mendapatkan produk pembelajaran, hasil pembelajaran, tentu akan diawali dengan proses pembelajaran. Proses melaksanakan proses pembelajaran tidak mengalami banyak kendala ketika bisa bertatap muka langsung dengan siswa di kelas nyata, demikian pula untuk menghasilkan produk, hasil pembelajaran, dapat dilakukan penilaian hasil belajar langsung setelah selesai proses atau bersamaan proses pembelajaran.

Dengan merebaknya wabah COVID-19, dimana pelaksanaan pembelajaran, tidak bisa dilaksanakan secara tatap muka dan kemudian ditindaklanjuti dengan 
dikeluarkannya regulasi-regulasi yang secara langsung maupun tidak langsung berdampak pada proses pembelajaran, termasuk di SMAN 4 Kota Bima dimana pembelajaran berlangsung sebagian besar dengan daring (dalam jaringan) dan kombinasi dengan blended (campuran daring dan tatap muka) 2020/2021. Keputusan Presiden Republik Indonesia Nomor 12 tahun 2020 Tentang Penetapan Bencana Nonalam Penyebaran Corona Virus Disesease 2019 (COVID-19) menyatakan bencana nonalam yang diakibatkan oleh penyebaran Corona Virus Disease 2019 (COVID-19) sebagai bencana nasional (Syarifuddin dkk, 2021).

Kondisi tersebut memacu dan mengharuskan peneliti melaksanakan proses pembelajaran belajar dari rumah (BDR) baik luar jaringan (luring) maupun dalam jaringan (daring), karena guru dituntut untuk melaksanakan pembelajaran RPP yang telah disusun. Pada pembelajaran pra-sikus, awal pembelajaran belajar dari rumah (BDR) dilaksanakan dengan non daring yakni mengirimkan materi pembelajaran dan tugas ke masing-masing siswa dan pada waktu tertentu siswa mengumpulkan tugas secara terjadwal di sekolah.

Dalam lampiran Permendikbud Nomor 22 Tahun 2016 Tentang Standar Proses disebutkan bahwa proses pembelajaran pada satuan pendidikan diselenggarakan secara interaktif, inspiratif, menyenangkan, menantang, memotivasi siswa untuk berpartisipasi aktif, serta memberikan ruang yang cukup bagi prakarsa, kreativitas, dan kemandirian sesuai dengan bakat, minat, dan perkembangan fisik serta psikologis siswa. Untuk itu setiap satuan pendidikan melakukan perencanaan pembelajaran, pelaksanaan proses pembelajaran serta penilaian proses pembelajaran untuk meningkatkan efisiensi dan efektivitas ketercapaian kompetensi lulusan. Hasil refleksi awal pembelajaran BDR luring pra siklus menunjukkan motivasi belajar siswa rendah dan berdampak pada rendahnya hasil belajar siswa. Pada pelaksanaan proses pembelajaran pra-siklus BDR secara luring memiliki beberapa kendala. Salah satu kendala terberat dalam pembelajaran luring adalah sulitnya mengontrol aktivitas siswa baik dalam proses pembelajaran di rumah berbasis buku teks dan tugas, maupun aktivitas siswa dalam mengumpulkan tugas. Motivasi siswa menunjukkan $60 \%$ siswa rendah, $25 \%$ sedang, $15 \%$ tinggi dan $0 \%$ sangat tinggi. Rendahnya motivasi belajar siswa ini berdampak pada rendahnya hasil belajar siswa pra-siklus yakni prestasi belajar siswa yang dicapai siswa rata-rata rendah yakni: 73.00 dengan ketuntasan klasikal $74.00 \%$. Hal ini masih dibawah indikator kinerja yang ditentukan yakni rata-rata $\geq 75.00$ dengan ketuntasan klasikal $\geq 85.00 \%$.

Kondisi tersebut mendorong peneliti untuk melaksanakan perbaikan pembelajaran BDR yang pada pra-siklus hanya menggunakan luring (luar jaringan) dengan berinovasi menerapkan pembelajaran daring (dalam jaringan) dengan memanfaatkan platform google form. Google form dipilih dalam pembelajaran daring dengan pertimbangan utamanya adalah praktis dan dapat melakukan transformasi informasi secara cepat dan tepat.

Pembelajaran daring bertujuan memberikan layanan pembelajaran bermutu dalam jaringan (daring) yang bersifat masif dan terbuka untuk menjangkau peminat yang lebih banyak dan lebih luas (Sofyana \& Rozaq, 2019). Pelaksanaan daring ini juga disebabkan regulasi ASN yang dalam kondisi tertentu diharuskan bekerja dari rumah. WFH adalah singkatan dari work from home yang berarti bekerja dari rumah. Kebijakan WFH tertuang dalam Surat Edaran Menteri Pendayagunaan Aparatur Negara dan Reformasi Birokrasi (PAN \& RB) Nomor 50/2020 tentang 
Perubahan Kedua atas Surat Edaran Menteri PAN \& RB Nomor 19/2020 tentang Penyesuaian Sistem Kerja Aparatur Sipil Negara dalam Upaya Pencegahan Penyebaran Covid-19 di Lingkungan Instansi Pemerintah. Sebagai ASN, guru dalam upaya melaksanakan proses pembelajaran perlu dilakukan secara daring (online) atau dalam jaringan (daring).

Menciptakan pembelajaran yang membangkitkan motivasi belajar siswa bukanlah pekerjaan yang mudah. Selama ini peneliti sebagai guru dalam menyampaikan pembelajaran cenderung mengabaikan kepentingan, potensi, minat dan bakat siswa. Siswa cenderung bekerja secara individual dalam menyelesaikan tugas-tugas. Kerja sama antar siswa relatif kurang intensif.

Penerapaan daring berbasis "Google Form" bertujuan untuk membantu guru dan siswa dalam mengorganisasi kelas serta berkomunikasi dengan siswa dengan jadwal pembelajaran yang lebih fleksibel. Penyampaian pembelajaran dengan elearning (daring) merupakan pembelajaran dengan memanfaatkan teknologi internet untuk meningkatkan lingkungan belajar dengan konten yang kaya dengan cakupan yang luas. E-learning merupakan pemanfaatan media pembelajaran menggunakan internet, untuk mengirimkan serangkaian solusi yang dapat meningkatkan pengetahuan dan keterampilan. (Sabran \& Sabara, 2019).

\section{KAJIAN TEORI}

\section{Hakikat Belajar}

Belajar adalah perkembangan yang berasal dari latihan dan usaha (Soeparwoto dkk 2007: 34). Belajar dapat terjadi melalui dua cara yaitu imitasi dan identifikasi. Imitasi artinya individu meniru yang dilakukan orang lain. Sedangkan identifikasi artinya individu menerima sikap, nilai, motivasi, dan perilaku orang yang dihormati atau dicintai. Gagne dan Berliner dalam Anni dkk (2007:2) mendefinisikan belajar merupakan proses dimana suatu organisme mengubah perilakunya karena hasil dari pengalaman.

Pengertian belajar menurut Slameto (2010: 2) adalah suatu proses usaha yang dilakukan seseorang untuk memperoleh suatu perubahan tingkah laku yang baru secara keseluruhan, sebagai hasil pengalamannya sendiri dalam interaksi dengan lingkungannya. Berdasarkan beberapa pengertian belajar, maka dapat disimpulkan bahwa belajar merupakan suatu proses perubahan sikap dan tingkah laku yang bersifat permanen yang disebabkan karena adanya pengaruh pengalaman dan lingkungan.

\section{Hakikat Aktivitas Belajar}

Menurut Sardiman dalam Saminanto (2010: 97) aktivitas belajar adalah keaktifan yang bersifat fisik maupun mental. Dalam proses pembelajaran keduanya harus saling menunjang agar diperoleh hasil belajar yang optimal.

Menurut Poerwadarminta dalam Yusfy (2011), aktivitas adalah kegiatan, sehingga aktivitas belajar adalah kegiatan-kegiatan siswa yang menunjang keberhasilan belajar. Slameto (2010: 36) berpendapat mengenai proses belajar mengajar bahwa dalam proses belajar mengajar, guru perlu menimbulkan aktivitas siswa dalam berpikir maupun berbuat. Aktivitas yang dilakukan siswa dalam proses pembelajaran tersebut akan meninggalkan kesan. Siswa tidak akan 
menghilangkan kesan tersebut begitu saja, tetapi dipikirkan, diolah, kemudian dikeluarkan lagi dalam bentuk yang berbeda.

Merujuk pendapat Dierich dalam Hamalik (2011: 172-3) ada delapan kelompok aktivitas belajar, yaitu:

1. Kegiatan-kegiatan visual, meliputi membaca, melihat gambar-gambar, mengamati, eksperimen, demonstrasi, pameran, dan mengamati orang lain bekerja atau bermain.

2. Kegiatan-kegiatan lisan (oral), meliputi mengemukakan suatu fakta atau prinsip, menghubungkan suatu kejadian, mengajukan pertanyaan, memberi saran, mengemukakan pendapat, wawancara, diskusi, dan interupsi.

3. Kegiatan kegiatan mendengarkan, meliputi mendengarkan penyajian bahan, percakapan atau diskusi kelompok, permainan, dan radio.

4. Kegiatan-kegiatan menulis, meliputi menulis cerita, laporan, memeriksa karangan, membuat rangkuman, mengerjakan tes, dan mengisi angket.

5. Kegiatan-kegiatan menggambar, meliputi menggambar, membuat grafik, chart, diagram peta, dan pola.

6. Kegiatan-kegiatan metrik, meliputi melakukan percobaan, memilih alat- alat, melaksanakan pameran, membuat model, menari, berkebun, dan menyelenggarakan permainan.

7. Kegiatan-kegiatan mental, meliputi merenungkan, mengingat, memecahkan masalah, menganalisis faktor-faktor, melihat hubunganhubungan, dan membuat keputusan.

8. Kegiatan-kegiatan emosional, meliputi minat, membedakan, berani, tenang, dan lain-lain.

Berdasarkan beberapa pengertian aktivitas yang telah dipaparkan, maka peneliti dapat menyimpulkan bahwa aktivitas belajar adalah segala kegiatan yang dilakukan siswa selama proses pembelajaran baik yang bersifat fisik maupun mental dan akan berpengaruh pada hasil belajar. Jadi, hasil belajar yang diperoleh siswa sangat bergantung pada bagaimana aktivitas belajar yang dilakukan selama pembelajaran.

\section{Hakikat Hasil belajar}

Hasil belajar merupakan perubahan perilaku yang diperoleh pembelajar setelah mengalami aktivitas belajar (Anni dkk 2007: 5). Menurut Suprijono (2011:5), hasil belajar adalah pola-pola perbuatan, nilai-nilai, pengertianpengertian, sikap-sikap, apresiasi, dan keterampilan. Hasil belajar menurut Bloom dalam Rifa'i dan Anni (2009: 86) digolongkan menjadi tiga domain, yaitu domain kognitif, afektif dan psikomotor. Domain kognitif berkenaan dengan pengembangan kemampuan otak dan penalaran siswa. Domain afektif berkenaan dengan sikap dan nilai. Domain psikomotor tampak dalam bentuk keterampilan dan kemampuan siswa dalam bertindak.

Menurut Gagne dan Briggs dalam Anni dkk (2007:12) mengklasifikasikan hasil belajar dalam lima kategori, yaitu: (1) kemahiran intelektual; (2) strategi kognitif ; (3) informasi verbal ; (4) kemahiran motorik ; dan (5) sikap. Berdasarkan paparan mengenai pengertian hasil belajar, maka dapat disimpulkan bahwa hasil belajar merupakan kemampuan yang dimiliki seseorang setelah mengalami proses belajar, baik yang bersifat langsung maupun tidak langsung (dampak 
pengiring). Hasil belajar akan lebih bermakna apabila proses pelaksanaannya menyenangkan dan terjadi penguatan.

\section{Hakikat Pembelajaran}

Undang-Undang No 20 tahun 2003 tentang Sistem Pendidikan Nasional Bab I Pasal 1 ayat 20 menjelaskan bahwa pengertian pembelajaran adalah proses interaksi peserta didik dengan pendidik dan sumber belajar pada suatu lingkungan belajar. Pembelajaran menurut Briggs dalam Sugandi (2007: 9) adalah seperangkat peristiwa yang mempengaruhi si belajar sedemikian rupa, sehingga memperoleh kemudahan dalam berinteraksi berikutnya dengan lingkungan.

Menurut Isjoni (2010:11) pembelajaran pada dasarnya merupakan upaya pendidik untuk membantu peserta didik melakukan kegiatan belajar. Menurut Siddiq dkk (2009: 1-9) pembelajaran adalah suatu upaya yang dilakukan oleh seseorang (guru atau yang lain) untuk membelajarkan siswa yang belajar. Pada pendidikan formal (sekolah), pembelajaran merupakan tugas yang dibebankan kepada guru, karena guru merupakan tenaga profesional yang dipersiapkan untuk itu.

Dari beberapa pengertian pembelajaran, maka peneliti dapat menyimpulkan pengertian pembelajaran adalah seperangkat peristiwa berupa interaksi siswa dengan pendidik dan sumber belajar lainnya untuk mencapai hasil belajar yang telah ditentukan pada suatu lingkungan belajar.

\section{Pembelajaran Fisika dalam Kurikulum 2013}

Dalam Kurikulum 2013, juga dikembangkan pembelajaran langsung dan tidak langsung. Pembelajaran langsung yang dimaksud adalah kegiatan pembelajaran yang disusun dalam Rencana Pelaksanaan Pembelajaran (RPP) agar peserta didik dapat mengembangkan pengetahuan, sikap, serta keterampilan dirinya. Sedangkan pembelajaran tidak langsung merupakan bagian dari pembelajaran langsung tetapi tidak disusun kegiatan pembelajaran untuk itu.

Pembelajaran langsung berkenaan dengan Kompetensi Inti (KI) 3 dan Kompetensi Inti (KI) 4 yang berturut-turut berisi tentang kompetensi pengetahuan dan kompetensi keterampilan yang harus dicapai peserta didik dan pembelajaran tidak langsung berkenaan dengan Kompetensi Inti (KI) 1 dan Kompetensi Inti (KI) 2 yang berisi tentang sikap spiritual dan sosial. Kedua pembelajaran ini terjadi secara terintegrasi dan tidak terpisah.Standar Penilaian Pendidikan adalah kriteria mengenai mekanisme,prosedur, dan instrumen penilaian hasil belajar peserta didik (Permendikbud no. 66 tahun 2013).Penilaian pada Kurikulum 2013 dilakukan dalam bentuk penilaian autentik yang merupakan instrument penilaian yang menilai mulai dari masukan (input), proses (process) dan hasil (output) pembelajaran mencakup sikap, pengetahuan dan keterampilan. Teknik penilaian yang digunakan relevan dengan proses pembelajaran saintifik, karena dapat menilai kemampuan peserta didik dalam proses serta hasil pembelajaran. Penilaian mengacu pada patokan ketuntasan belajar (Permendikbud nomor 81A tahun 2013). Apabila peserta didik dapat mencapai Kompetensi Dasar (KD) yang dikembangkan dari KI-3 dan KI-4 dengan nilai lebih dari atau sama dengan 2,66 dinyatakan sudah tuntas. Jika di bawah nilai itu, dinyatakan belum tuntas dan segera dilakukan program remedial.

Sedangkan penilaian pada kompetensi sikap (KI-1 dan KI-2) dilakukan dengan melihat profil sikap peserta didik secara umum pada semua mata pelajaran, jika 
nilainya berkategori baik (B) maka dinyatakan lulus, tetapi jika di bawah B, yakni C dan K harusdilakukan pembinaan secara holistik oleh guru Bimbingan dan Konseling (BK), guru mata pelajaran, dan orang tua. Pembelajaran dengan pendekatan belajar tuntas membutuhkan peran guru agar mendorong keberhasilan peserta didik. Apabila peserta didik sudah tuntas, guru dapat memberikan penguatan materi berupa pengayaan atau pun melanjutkan materi pada kompetensi selanjutnya. Tetapi, apabila peserta didik belum tuntas atau gagal mencapai kompetensi, maka guru harus memberikan remedial kepada peserta didik hingga mencapai ketuntasan. Implikasi dari prinsip pembelajaran tuntas ini mengharuskan dilaksanakannya programprogram remedial dan pengayaan sebagai bagian dalam penerapan belajar tuntas. Oleh karena itu, setiap guru harus memiliki kemampuan memberikan remedial secara tepat sesuai kebutuhan dan karakteristik balajar peserta didik agar mencapai ketuntasan kompetensi.

\section{Standar Kompetensi Lulusan}

Kurikulum 2013 mencakup kompetensi pengetahuan (kognitif), sikap (afektif), dan keterampilan (psikomotor) yang diharapkan dapat dimiliki peserta didik setelah menyelesaikan suatu jenjang pendidikan (Permendikbud no. 54 tahun 2013). Standar Kompetensi Lulusan diimplementasikan ke dalam pembelajaran melalui Kompetensi Inti yang merupakan tingkat kemampuan yang harus dicapai oleh peserta didik dalam suatu jenjang pendidikan tertentu. Kompetensi Inti memuat 4 aspek, yaitu (1) Keagamaan; (2) Sosial; (3) Pengetahuan; dan (4) Keterampilan. Melalui aspek-aspek ini diharapkan setelah lulus dari jenjang pendidikan peserta didik memiliki sikap beriman, rendah hati, mulia, menggunakan ilmunya untuk bangsa dan negara dan memiliki kreativitas.

\section{Kompetensi Dasar}

Kompetensi yang harus dicapai peserta didik untuk setiap mata pelajaranuntuk mencapai Kompetensi Inti. Standar Isi merupakan kriteria mengenai ruang lingkup materi dantingkat kompetensi peserta didik untuk mencapai kompetensi lulusan padajenjang pendidikan (Permendikbud no. 64 tahun 2013).

\section{Ruang lingkup materi dan tingkat kompetensi}

Peserta didik yang harusdicapai dirumuskan dalam Standar Isi untuk setiap matapelajaran SMA/MA terdiri dari wajib dan pilihan. Kelompok mata pelajaran wajib terdiri dari kelompok A dan B, sama seperti SMP/MTs. Kelompok mata pelajaran peminatan terdiri dari Fisika dan Sains, Ilmu Sosial dan Bahasa.Selain itu, peserta didik juga memungkinkan mengikuti mata pelajaran lintas minat.Standar Proses adalah kriteria mengenai pelaksanaan pembelajaran padasatuan pendidikan untuk mencapai Standar Kompetensi Lulusan (Permendikbud no. 65 tahun 2013).

Pada Kurikulum 2013, tugas seorang guru adalah membuat Rancangan Pelaksanaan Pembelajaran (RPP) dan memaksimalkan proses pembelajaran. Pembelajaran menggunakan pendekatan pembelajaran saintifik yaitu kegiatan pembelajaran yang mengadopsi langkah-langkah ilmuwan dalam membangun pengetahuanyang terdiri dari mengamati, menanya, mencoba, menalar dan mengkomunikasikan. Pelaksanaan pembelajaran Kurikulum 2013 tidak berpusat pada guru, melainkan pada peserta didik dengan harapan dapat menjadikan peserta didik aktif, mandiri, dan disiplin dalam mencari pengetahuan layaknya seorang 
ilmuwan, tidak hanya memperoleh pengetahuan, sikap, dan keterampilan saja, tetapi yang lebih penting adalah bagaimana proses yang dilakukan peserta didik dalammendapatkan pengetahuan itu.

\section{Google Form}

\section{Pembelajaran dalam jaringan (daring)}

Pembelajaran dalam jaringan (daring) atau disebut juga berbasis daring (daring (online)) suatu kegiatan pembelajaran dengan mengunakan internet sebagai sarana utama untuk menyelasaikan pekerjaan. Selain internet, sarana lain yang dibutuhkan adalah aplikasinya daring (daring (online)) dan perangkat computer. Dalam konteks saat ini eran komputer bisa disubstitusikan dengan smartphone bagi peserta didik. Pembelajaran daring (daring (daring (online))) memanfaatkan fitur server untuk mengelola dan menyimpan data.

Pengertian daring (daring (daring (online))) merupakan kebalikan dari luring (offline). Kata daring (daring (online)) itu berasal dari kata on dan line, on artinya hidup, line artinya saluran. Pengertian daring (daring (online)) adalah keadaan komputer yang teroneksi/ terhubung ke jaringan internet. Sehingga apabila komputer kita daring (daring (online)) maka dapat mengakses internet/ browsing, mencari informas-informasi di internet.

\section{Google form}

Google form, adalah layanan daring (daring (online)) dari google untuk membuat formulir daring (daring (online)), dan untuk mengumpulkan data, komentar, yang nantinya dapat disusun mengunakan spreadsheet.

Disini penulis akan memberikan cara untuk membuat soal daring (daring (online)), soal tersebut tidak hanya soal pilihan essay, tetapi juga dapat membuat soal pilihan ganda, yang nantinya dapat kita tampilkan ke halaman blog untuk kemudian dibagikan kepada peserta didik dan peserta didik dapat mengisinya hanya dengan membuka halaman blog tersebut dan mengisi jawaban.

Pengertian lain tentang google form adalah merupakan salah satu layanan yang diberikan google untuk kelola pendaftaran acara, jejak pendapat, membuat kuis, dan melakukan kuis secara daring (daring (online)). Pada googleform terdapat tanggapan survei yang diolah menjadi sebuah grafik lingkaran.

Googleform merupakan salah satu komponen layanan googledocs. Aplikasi ini sangat cocok untuk siswa, guru, dosen, pegawai kantor dan professional yang senang membuat quiz, form dan survey daring (daring (online)), fitur dari GoogleForm dapat dibagi ke orang-orang secara terbuka atau khusus kepada pemilik akun Google dengan pilihan aksesibilitas, seperti readonly (hanya dapat membaca) atau editable (dapat mengedit dokumen). memiliki akun universal Google.

\section{Fungsi Google Form}

Adapun beberapa fungsi GoogleForm untuk dunia pendidikan adalah sebagai berikut:

a. Memberikan tugas latihan/ ulangan daring (daring (online)) melalui website.

b. Mengumpulkan pendapat orang lain melalui laman website.

c. Mengumpulkan beberapa data siswa/guru melalui laman website.

d. Membuat formulir pendaftaran daring (daring (online)) untuk sekolah. 
e. Membagikan kuesioner kepada orang-orang secara daring (daring (online)).

\section{Keunggulan Google Form}

Adapun beberapa keungulan pada pembelajaran mengunakan Google From adalah:

a. Tampilan Form yang menarik. Aplikasi inimenyediakan fasilitas kepada penggunanyauntuk memasukkan dan meng guna kan fotoatau logonya sendiri di dalam survey tersebut.Aplikasi ini juga memiliki banyak templateyang membuat kuis dan kuesioner daring (daring (online))tersebut semakin menarik dan berwarna.

b. Memiliki berbagai jenis tes yang bebas dipilih. Aplikasi ini menyediakan fasilitas pilihan tes yang bebas digunakan sesuai dengan keperluan pengguna. Misalnya pilihan jawaban pilihan ganda, ceklis, tarik-turun, skala linier, dan lain sebagainya. Anda juga dapat menambahkan gambar dan video YouTube ke dalam kuis anda.

c. Responden dapat memberikan tanggapan dengan segera di mana pun. Aplikasi ini dapat digunakan setiap orang secara gratis untuk membuat kuisioner daring (daring (online)) dan kuis daring (daring (online)) menggunakan laptop atau handphone yang terhubung dengan internet lalu membagikan alamat link formnya kepada para responden sasaran atau menempelkannya di sebuah halaman website. Para respondennya dapat memberikan tanggapannya dimanapun dan kapanpun dengan mengklik alamat web atau link yang dibagikan pembuat kuisioner tersebut menggunakan komputer atau handphone yang terhubung ke internet. Semua tanggapan dan jawaban orang lain akan secara otomatis ditampung, disusun, dianalisa dan disimpan oleh aplikasi GoogleForm dengan cepat dan aman.

d. Formulirnya responsive. Berbagai jenis kuis dan kuesioner dapat dibuat dengan mudah, lancar dan hasilnya tampak profesional dan indah.

e. Hasilnya langsung tersusun dianalisis secara otomatis. Tanggapan survei anda dikumpulkan dalam formulir dengan rapi dan secara otomatis, disertai info tanggapan waktu nyata dan grafik hasil tanggapan. Pengguna juga dapat melangkah lebih jauh bersama hasil data dengan melihat semuanya di Spreadsheet, yakni aplikasi semacam Ms. OfficeExcel.

f. Dapat dikerjakan bersama orang lain. Kuisioner dan Quiz menggunakan aplikasi ini dapat dikerjakan bersama orang lain atau siapa saja yang diinginkan oleh pengguna (Aminah dkk, 2021; Khotimah dkk, 2021).

\section{METODE PENELITIAN}

\section{Subyek Perbaikan}

\section{Lokasi Waktu dan Subyek Perbaikan}

a. Lokasi Perbaikan

Perbaikan ini dilakukan di SMAN 4 Kota Bima yang bertempat di Kota Bima.

b. Waktu Perbaikan

Perbaikan dilaksanakan dalam 2 (dua) siklus. Siklus I dari tanggal 17 Juli 2020

sampai dengan tanggal 24 Juli 2020 dan siklus II dilaksanakan tanggal 10 Agustus 2020 sampai dengan 20 Agustus 2020.

c. Mata Pelajaran 
Mata pelajaran yang dilakukan perbaikan adalah Fisika Kelas XII MIPA-1.

\section{Subyek Perbaikan}

Subyek perbaikan adalah siswa SMP SMAN 4 Kota Bima dengan jumlah siswa 30 , terdiri dari 14 orang laki-laki dan 16 orang perempuan.

\section{Faktor Yang diteliti}

Adapun faktor-faktor yang akan diteliti adalah:

- Motivasi belajar, dilakukan dengan tahap observasi terhadap siswa dengan kuisioner berbasis google form secara daring melalui Whatsapp (WA).

- Hasil Belajar, dilakukan dengan memberikan tes daring berbasis google form secara daring melalui Whatsapp (WA).

- Kinerja guru, diteliti sejauh mana ketuntasan guru dalam melaksanakan dan menyelesaikan rencana pelaksanaan pembelajaran.

\section{Prosedur Perbaikan}

1) Data dan Cara Pengambilannya

a) Sumber data: sumber data perbaikan ini adalah seluruh siswa SMAN 4 Kota Bima.

b) Jenis data:

(1) Data kualitatif terdiri dari:

(a) Teacher's note (Rancangan Pembelajaran)

(b) Data hasil observasi pelaksanaan pembelajaran dan activitas siswa.

(c) Jurnal tim peneliti

(2) Data Kuantitatif

(a) Nilai pos tes

c) Teknik Pengambilan data

a) Data kualitatif diambil dari teacher's note (rencana pembelajaran) yang dibuat peneliti.

b) Data tentang refleksi diri diambil dari jurnal yang dibuat oleh peneliti.

c) Data kuantitatif diambil dari skor nilai tes siswa.

2) Indikator Kinerja

a) Motivasi belajar

b) Hasil belajar, rata-rata nilai post test $\geq 75.00$ dengan porsentase ketuntasan $85.00 \%$.

3) Intrumen Perbaikan

a) Instrumen perbaikan berupa performance test.

b) Lembar observasi kinerja guru.

\section{Deskripsi Per-siklus/Desain Perbaikan}

\section{Siklus Perbaikan}

Siklus perbaikan dilaksanakan dalam dua siklus siklus. Tiap siklus terdiri dari 4 (empat) tahapan utama yakni: perencanaan; penerapan tindakan; observasi dan refleksi. Hasil refleksi akan menentukan apakah PTK dalam siklus tersebut berhasil atau belum berhasil. Jika belum berhasil maka akan dilanjutkan pada siklus berikutnya.

\section{Rincian Prosedur Perbaikan}




\section{Siklus Pertama}

Tahap-tahap perbaikan tindakan siklus pertama

a) Perencanaan

Dalam tahap perencanaan ini kegiatan pokok yang dilakukan adalah: Tahap perencanaan merupakan awal yang harus dilakukan guru sebelum melakukan suatu tindakan sehingga kegiatan yang akan dilakukan lebih terarah. Pada tahap perencanaan ini peneliti menyiapkan lembar kuesioner daring (online), kelas daring (online) di Google Form, absen daring (online) form, kuis e- learning google form tentang materi yang sudah dipelajari, dan materi yang berkenaan dengan pelajaran di kelas serta menjelaskan kepada kelas mengenai prosedur kelas daring daring (online) berbasis google form.

b) Penerapan Tindakan

Penelitian ini dilakukan dengan 2 siklus sesuai absen pertemuan 1 sampai 4 karena kelas daring (online) penelitian ini guru hanya memberikan izin penelitian yang tidak membebani siswa dan siswa punya jadwal kelas daring (online) dengan guru matapelajaran yang tidak bisa diganggu.

Langkah-langkah pembelajaran dengan menggunakan Google Form (disini peneliti bertugas sebagai guru di kelas daring (online) Google Form yang dibuat) yaitu:

1. Guru memberikan materi penjelasan berbasis Google Form dan absen di Google Form.

2. Guru memberikan contoh soal pemecahan masalah berkenaan dengan materi di classroom dan absen menggunakan google form.

3. Guru memberikan kuis e-learning google form untuk meningkatkan motivasi belajar dan menambah pengetahuan mengenai kuis yang dilakukan secara daring (online).

4. Guru memberikan tugas untuk dikumpulkan pada pertemuan selanjutnya di Google Form.

c) Observasi dan pembagian Angket menggunakan Google Form

Observasi dilakukan bersamaan dengan waktu pelaksanaan tindakan oleh peneliti dan menggunakan lembar observasi setiap diadakan tugas dan pertemuan kelas di Google Form. Lembar observasi digunakan oleh observer dalam mengamati tingkah laku siswa yang merupakan cerminan dari aspek motivasi belajar Fisika. Hasil pengamatan tersebut digunakan sebagai data pendukung angket motivasi belajar Fisika. Lembar observasi dianalisis secara kualitatif.

\section{Siklus Kedua}

Kegiatan pada siklus kedua merupakan rangkaian kegiatan yang tidak teroisahkan dengan kegiatan siklus pertama. Langkah-langkah kegiatan siklus kedua tidak jauh berbeda dengan siklus pertama. Disini langkah-langkah direncanakan dan dilaksanakan berdasarkan hsil refleksi Penerapan tindakan siklus pertama. Langkahlangkah utama tersebut adalah:

1. Perencanaan

2. Penerapan tindakan

3. Observasi dan

4. Refleksi 


\section{Teknik Pengumpulan dan Analisis Data}

\section{Data Motovasi belajar}

Pengumpulan data dalam penelitian ini menggunakan teknik angket Google Form dan observasi yang dilakukan melalui kelas Daring berbasisi Google Form. Teknik angket digunakan untuk mengetahui persentase dari tingkat motivasi belajar Fisika setiap siswa. Teknik observasi digunakan sebagai data pendukung melalui pengamatan yang menunjukkan tingkat motivasi belajar siswa ketika pembelajaran Fisika di kelas Daring.

Teknik analisis data untuk angket motivasi belajar secara deskriptif kuantitatif. Metode penskoran angket motivasi belajar siswa didasarkan pada skala Likert dengan 4 pilihan jawaban. Pilihan jawaban yang disediakan untuk angket motivasi belajar Fisika antara lain:

- 4 = sangat setuju,

- 3 = setuju,

- 2 = tidak setuju,

- 1 = sangat tidak setuju.

Motivasi belajar Fisika dikelompokkan menjadi tiga kategori, yaitu tinggi, sedang, dan rendah. Teknik analisis data untuk mengetahui kategori motivasi belajar Fisika melalui angket dilaksanakan dengan mengakumulasikan skor dari semua butir angket dari semua sampel penelitian.

Skor tersebut kemuadian diolah untuk menentukan rata-rata skor motivasi belajar. Rata-rata digunakan sebagai patokan untuk mengkategorikan tingkat motivasi belajar tiap siswa untuk mata pelajaran Fisika. Kriteria pengelompokan kategori/kriteria kuesioner motivasi belajar siswa untuk mata pelajaran Fisika disajikan pada Tabel.

Tabel 1. Variabel dan Instrumen penelitian Motivasi Belajar Siswa

\begin{tabular}{|c|c|c|c|}
\hline $\begin{array}{l}\text { Variabel } \\
\text { terkait }\end{array}$ & Indikator & Data & Instrumen \\
\hline \multirow[t]{6}{*}{ Motivasi } & $\begin{array}{l}\text { 1. Hasrat dan } \\
\text { keinginan berhasil. }\end{array}$ & \multirow[t]{6}{*}{$\begin{array}{l}\text { Skor Rata- } \\
\text { Rata Kelas }\end{array}$} & \multirow{6}{*}{$\begin{array}{l}\text { Kuesioner } \\
\text { motivasi } \\
\text { belajar siswa }\end{array}$} \\
\hline & $\begin{array}{l}\text { 2. Dorongan dan } \\
\text { kebutuhan dalam } \\
\text { belajar. }\end{array}$ & & \\
\hline & $\begin{array}{l}\text { 3. Adanya harapan dan } \\
\text { cita-cita. }\end{array}$ & & \\
\hline & $\begin{array}{l}\text { 4. Adanya } \\
\text { pembelajaran dan } \\
\text { penghargaan. }\end{array}$ & & \\
\hline & 5. Kegiatan menarik. & & \\
\hline & 6. Belajar kondusif & & \\
\hline
\end{tabular}

Peneliti menggunakan 6 indikator motivasi belajar menurut Uno (2015). Indikator tersebut adalah hasrat dan keinginan berhasil, dorongan dan kebutuhan dalam belajar, adanya harapan dan cita-cita masa depan, adanya penghargaan dalam pembelajaran, kegiatan menarik, dan lingkungan belajar yang kondusif. 
Tabel 2. Kriteria skor observasi dan kuesionar Motivasi Belajar

\begin{tabular}{|c|l|l|}
\hline No & Koefisien Korelasi & \multicolumn{1}{|c|}{ Kualifikasi } \\
\hline 1. & $0-50$ & Rendah \\
\hline 2. & $51-70$ & Sedang \\
\hline 3. & $80-100$ & Tinggi \\
\hline
\end{tabular}

Langkah selanjutnya adalah menentukan persentase (\%) dari tiap kategori motivasi belajar. Motivasi belajar Fisika yang dikategorikan menjadi kelompok motivasi tinggi, sedang, dan rendah ditentukan persentasenya untuk mengetahui tingkatan motivasi belajar siswa secara umum ketika belajar Fisika kelas daring menggunakan Google Form. Cara menentukan persentase tiap kategori motivasi belajar Fisika adalah sebagai berikut.

Keterangan:

A : kategori motivasi belajar siswa tinggi/ sedang/rendah, dengan satuan persen $(\%)$.

$\mathrm{N}$ : jumlah siswa yang memiliki motivasi belajar tinggi/sedang/rendah.

$\mathrm{T}$ : jumlah seluruh siswa atau sampel penelitian.

\section{Tes Hasil Belajar}

Dalam penelitian yang menggunakan instrumen penelitian tes ini yang akan diukur adalah tingkat pemahaman siswa yang nantinya merupakan Hasil Belajar pada ranah kognitif. Tes yang digunakan dalam penelitian ini adalah jenis tes objektif berbentuk pilihan ganda (multiple choice), uraian.

Tes ini berfungsi untuk mengumpulkan data tentang Hasil Belajar siswa dalam upaya peningkatan Hasil Belajar pada ranah kognitif siswa akibat perlakuan (treatment). Tes untuk mengukur Hasil Belajar ranah kognitif dilakukan pada awal sebelum dilakukan tindakan, yaitu berupa pre test dan pada setiap akhir siklus atau disebut post test. Dalam menyusun tes ini dibuat kisi-kisi soal tes terlebih dahulu yang terdapat dalam (lampiran). Kisi-kisi angket yang akan digunakan adalah sebagai berikut.

\section{Indikator Keberhasilan}

\section{Motivasi Belajar}

Penelitian ini dikatakan berhasil jika pada setiap siklusnya motivasi belajar siswa mengalami peningkatan. Motivasi belajar siswa dinyatakan berhasil apabila minimal $75 \%$ siswa motivasi belajar tinggi, dan maksimal $10 \%$ siswa motivasi belajar rendah.

2. Hasil Belajar

Penelitian ini dikatakan berhasil jika pada setiap siklusnya Hasil Belajar ranah kognitif siswa mengalami peningkatan nilai rata-rata kelas dari pre-test ke post-test dan minimal 75\% mencapai kriteria ketuntasan minimal (KKM) yang telah ditentukan oleh sekolah yaitu 75 pada nilai post test.

Meningkatnya rata-rata hasil belajar yang dicapai siswa pada post test dari siklus I ke siklus II. Besarnya peningkatan nilai rata-rata pre test ke post test pada siklus I mengalami kenaikan pada siklus II. 


\section{HASIL DAN PEMBAHASAN}

\section{Deskripsikan Data per Siklus}

\section{Hasil Perbaikan}

\section{a) Perencanaan}

Data dengan aktivitas guru dan siswa selama proses pembelajaran secara daring (online) dikumpulkan dengan analisis respon peserta didik terhadap intruksi selama proses pembelajaran secara daring berbasis Google Form dan partisipasi siswa terhadap tugas dan materi yang diberikan. Aktivitas guru dinilai sesuai dengan RPP yang telah dirancang. Peneliti menambahkan beberapa program e-learning yaitu materi daring (online) yang diberikan di blog milik peneliti, absen daring (online) menggunakan google form, kuis daring (online) melalui google form untuk meningkatkan motivasi belajar yang dibagikan di kelas Daring Google Form.

b) Penerapan Tindakan

Pada pertemuan perkenalan, peneliti membuat kesepakantan dengan siswa untuk memanfaatkan WA dalam pembelajaran Fisika dan pada saat yang ditentukan secara sistemik terjadwal siswa membuka link, tautan google form. Dalam hal ini guru (peneliti) memberikan petunjuk melalui WA yang telah dibuat untuk kelas penelitian Kelas XII MIPA-1, peneliti mengarahkan agar siswa login ke Google Form dengan kode kelas yang telah dibagikan. Selanjutnya memberikan contoh, praktek langsung mengisi daftar hadir melalui link, tautan yang didesain peneliti. Setelah siswa login ke Google Form dikelas yang diintruksi oleh peneliti, peneliti membuat panduan dan pengarahan di Google Form dan membagikan link blog tentang materi teori relativitas khusus Kelas XII MIPA-1.

Pada pertemuan pertama yaitu, peneliti memberikan intruksi dan pengumuman di WA mengenai pertemuan dan kuis ltihan daring (online) soalnya tentang Teori relativitas newton. Kuis ini diberikan batas waktu tertentu. Sampai waktu yang ditentukan peneliti menunggu dan mengecek setiap pekerjaan siswa siswa yang login ke Google Form untuk mengetahu nilai yang diperoleh siswa. Pada tahap awal menangani belajar daring (online) dan kuis daring (online) masih terdapat 7 siswa yang belum mengirimkan jawaban kuis.

Pada pertemuan kedua, peneliti memberikan materi berupa LKS yang dibuat oleh peneliti mengenai materi teori relativitas khusus serta modul materi teori relativitas khusus untuk Kelas XII MIPA-1. Peneiliti juga memberikan intruksi agar siswa mengisi absen di kolom komentar Google Form. Dan pada pertemuan ini ada 27 siswa yang memberikan respon di kolom komentar.

Pada pertemuan ketiga, peneliti memberikan panduan di Google Form mengenai pertemuan, siswa di arahkan untuk mengisi absen google form di link yang dibagikan, serta materi dan tugas yang diberikan. Materi yang diberikan adalah contoh soal pemecahan masalah mengenai materi teori relativitas khusus yang dibuat oleh peneliti. Selanjutnya, Tugas yang diberikan adalah membuat contoh soal soal pemecahan masalah dengan materi yang pernah dipelajari. Sampai batas pertemuan selanjutnya yang mengumpulkan tugas hanya satu orang tetapi nilai dan hasilnya sangat memuaskan, dan ini juga bisa membuktikan bahwa siswa sudah paham mengenai materi teori relativitas khusus sehingga bisa berpikir kreatif ketika membuat tugas contoh soal pemecahan masalah barisan dan deret serta telah mengerti cara mengaplikasikan Google Form yaitu mengumpulkan tugas yang 
diinstruksikan dengan baik. Pada pertemuan ini hanya 10 orang mengisi absen di google form.

Pada pertemuan keempat, peneiliti memberikan pengumumuan dan instruksi mengenai pertemuan, absen di google form, memberikan kuis daring (online), serta menghimbau kembali kepada siswa yang belum mengisi absen pertemuan sebelumnya agar segera diisi, dan mengingatkan kepada siswa yang belum mengumpulkan tugas dan belum login kuis daring (online) agar segera dilaksanakan.

Selama melaksakanakan proses pembelajaran secara daring di Google Form, peneliti melakukan observasi dan menilai bahwa siswa lebih suka belajar secara tatap muka karena pelajaran Fisika menurut mereka saat proses tatap muka saja sulit untuk dipahami apalagi dilakukan secara metode daring, maka lebih sulit untuk dipahami. Tetapi dari hasil tugas yang dikumpulkan oleh siswa walaupun satu orang, dapat diketahui bahwa pemahaman mereka selama melakukan pembelajaran secara daring dengan guru matapelajarannya pada materi teori relativitas khusus Kelas XII MIPA-1, siswa telah mempelajari dan memahami materi dengan baik sehingga bisa menyelesaikan tugas yang diberikan oleh peneliti secara baik dan bagus. Dan siswa tersebut telah melakukan login ke kuis e-learning google form, dan mendapatkan nilai yang cukup memuaskan.

c) Observasi

Kegiatan observasi dilakukan oleh observer mengamati jalannya proses pembelajaran. Dalam observasi ini observer menggunakan lembar observasi dimana dalam format lembar observasi mengacu pada RPP yang peneliti rancang secara khusus. Tiap item diberi skor 1 apabila dilaksanakan dengan tuntas oleh guru dan diberi skor 0 bila tidak. Ketuntasan guru dalam melaksanakan dan menyelesaikan Rencana Pembelajaran disajikan dalam prosen (\%). Observasi motivasi belajar siswa diakukan dengan menggunakan angket menggunakan Google Form. Untuk hasil belajar siswa menggunakan pos tes dengan soal pilihan ganda dengan menggunakan Google Form yang didesain khusus sehingga hasilnya dapat langsung diketahui oleh peneliti. Adapun data hasil belajar siklus I dan siklus II dapat ditampilkan sebagai berikut :

Tabel 3. Motivasi belajar

\begin{tabular}{|l|l|l|l|l|l|l|l|l|}
\hline \multicolumn{3}{|c|}{ Pra Siklus } & \multicolumn{3}{c|}{ Sikus I } & \multicolumn{3}{c|}{ Siklus II } \\
\hline Tinggi & Sedang & Rendah & Tinggi & Sedang & Rendah & Tinggi & Sedang & Rendah \\
\hline $23,33 \%$ & $30 \%$ & $46,67 \%$ & $53,33 \%$ & $26,67 \%$ & $20 \%$ & $76,67 \%$ & $13,33 \%$ & $6,67 \%$ \\
\hline
\end{tabular}

Tabel 4. Hasil belajar siswa

\begin{tabular}{|c|c|c|c|c|c|}
\hline \multicolumn{2}{|c|}{ Pra Siklus } & \multicolumn{2}{c|}{ Sikus I } & \multicolumn{2}{c|}{ Siklus II } \\
\hline $\begin{array}{c}\text { Rata- } \\
\text { rata }\end{array}$ & $\begin{array}{c}\% \\
\text { ketercapaian }\end{array}$ & $\begin{array}{c}\text { Rata- } \\
\text { rata }\end{array}$ & $\begin{array}{c}\% \\
\text { ketercapaian }\end{array}$ & $\begin{array}{c}\text { Rata- } \\
\text { rata }\end{array}$ & $\begin{array}{c}\% \\
\text { ketercapaian }\end{array}$ \\
\hline 73.00 & 74.00 & 74.00 & 78.00 & 80.60 & 89.00 \\
\hline
\end{tabular}

d) Refleksi:

Berdasarkan pelaksanaan pembelajaran melalui penerapan pembelajaran daring (online) berbasis Google Form pada mata pelajaran Fisika materi teori relativitas khusus, Siklus I masih terdapat beberapa kekurangan yang perlu diperbaiki pada siklus berikutnya yakni: 
1. Guru perlu membimbing dan memotivasi siswa sehingga seluruh siswa dapat secara aktif mengikuti seluruh aktivitas pembelajaran baik melalui pengiriman respons, mengerjakan kuis serta mengikuti dan mengisi tes.

2. Dalam memberikan panduan, petunjuk baik melalui WA maupun dalam woorsheet Google Form guru perlu meemberikannya dengan jelas dan memberi kesempatan siswa untuk bertanya apabila kurang jelas memahami panduan, petunjuk.

3. Guru perlu secara berkala memberikan umpan balik pelaksanaaan kegiatan secara kalsikal maaupun secara individual, untuk perbaikn pembelajaran berikutnya.

\section{Pembahasan Per Siklus}

\section{Siklus I (Pertama)}

\section{a. Pembahasan Siklus I}

1) Motivasi belajar

Data motivasi belajar siklus I diatas menunjukkan bahwa motivasi belajar siswa kategori tinggi 53,33\%, kategori sedang 26,67\% dan kategori rendah $20 \%$. Motivasi belajar siswa menujukkan peningkatan dibanding dengan pra siklus, akan tetapi dari aspek motivasi belajar siswa pada siklus I belum mencapai indikator kinerja yang ditentukan yakni Penelitian ini dikatakan berhasil jika pada setiap siklusnya motivasi belajar siswa mengalami peningkatan. Motivasi belajar siswa dinyatakan berhasil apabila minimal 75\% siswa motivasi belajar tinggi, dan maksimal $10 \%$ siswa motivasi belajar rendah. Dengan demikian indikator motivasi belajar siklus I (pertama) belum berhasil.

\section{2) Hasil belajar siswa}

Hasil pos tes siklus I diatas menunjukkan bahwa hasil belajar siswa Fisika rata-rata 74.00 meskipun nilai rata-rata ini telah mengalami peningkatan dibanding pra sklus, sebelum diadakan perbaikan $(+1.00)$, tetapi nilai ini belum memenuhi indikator kinerja yang ditetapkan yakni rata-rata $\geq 75.00$. Prosentase ketuntasan klasikal $78.00 \%$ mengalami peningkatan dibanding pra siklus, sebelum diadakan perbaikan $(+3.80)$, Prosentase ini masih dibawah indikator kinerja yakni $\geq 85 \%$. Dari sisi prestasi belajar siklus I (pertama) belum berhasil.

\section{b. Pembahasan Siklus Kedua (II)}

\section{a. Hasil perbaikan \\ (1) Perencanaan}

Perencanaan siklus II dilakukan dengan mempertimbangkan hasil refleksi siklus I. Fokus perencanaan pada rencana perbaikan pelaksanaan proses pembelajaran.

(2) Penerapan Tindakan

Pelaksanaan tindakan siklus II urutannya tidak jauh berbeda dengan siklus I, akan tetapi dilakukan perbaikan sesuai hasil refleksi siklus I. Pada siklus II ini guru telah berhasil memperbaiki kekurangan-kekurangan pada siklus I yakni:

1. Guru berhasil membimbing dan memotivasi siswa sehingga seluruh siswa dapat secara aktif mengikuti seluruh aktivitas pembelajaran baik melalui pengiriman respons, mengerjakan kuis serta mengikuti dan mengisi tes. 
2. Dalam memberikan panduan, petunjuk baik melalui WA maupun dalam woorsheet Google Form guru telah mampu memberikannya dengan jelas dan serta memberi kesempatan siswa untuk bertanya apabila kurang jelas memahami panduan, petunjuk dan guru secara aktif memberikan penjelasan apa yang ditanyakan oleh siswa baik secara klasikal maupun individual melalui WA maupun Google Form.

3. Guru secara berkala telah memberikan umpan balik pelaksanaaan kegiatan secara kalsikal maaupun secara individual, untuk perbaikn pembelajaran berikutnya.

Setelah beberapa kali pertemuan melaksanakan pembelajaran sesuai dengan RPP dan jadwal yang ditentukan dengan metode daring di Google Form, maka peneliti melakukan pembagian kuesioner untuk mengetahui motivasi siswa di pembelajaran Fisika. Angket diisi oleh 30 siswa yang menjadi peserta di Google Form. Pada pertemuan terakhiir dilakukan pos tes bentuk soal pilihan ganda materi teori relativitas khusus.

(3) Observasi

Dalam kegiatan ini langkah-langkah tidah jauh berbeda dengan yang dilaksanakan pada siklus I. Observer menggunakan lembar observasi motivasi belajar siswa dan kinerja guru untuk mengamati seluruh pelaksanaan proses pembelajaran.

1) Motivasi belajar

Data motivasi belajar siklus II diatas menunjukkan bahwa motivasi belajar siswa kategori tinggi 76,67\%, kategori sedang $13,33 \%$ dan kategori rendah 6,67\%. Motivasi belajar siswa menujukkan peningkatan dibanding dengan siklus I. Dari aspek motivasi belajar siswa pada siklus II telah mencapai indikator kinerja yang ditentukan yakni penelitian ini dikatakan berhasil jika pada setiap siklusnya motivasi belajar siswa mengalami peningkatan. Motivasi belajar siswa dinyatakan berhasil apabila minimal $75 \%$ siswa motivasi belajar tinggi, dan maksimal $10 \%$ siswa motivasi belajar rendah. Dengan demikian indikator motivasi belajar siklus II (kedua) telah berhasil.

2) Hasil belajar siswa

Hasil pos tes siklus II diatas menunjukkan bahwa hasil belajar siswa Fisika rata-rata 80.60. Nilai rata-rata ini telah mengalami peningkatan dibanding siklus I $(+6.60)$. Prosentase ketuntasan $89.00 \%$, mengalami peningkatan dibanding siklus I (+11.00). Prosentase ini telah memenuhi indikator kinerja yakni $\geq 85.00 \%$. Dengan demikian pada siklus II ini telah berhasil mencapai indikator yang ditetapkan yakni rata-rata $\geq 75.00$ dan prosentase ketuntasan $\geq 85.00 \%$. Dari sisi prestasi belajar siklus II (kedua) telah berhasil.

(4) Refleksi

Berdasarkan hasil pelaksanaan Siklus I dan II melalui penerapan pembelajaran daring (online) berbasis Google Form pada mata pelajaran Fisika materi teori relativitas khusus untuk meningkatkan hasil belajar siswa di Kelas XII MIPA-1 Semester I SMAN 4 Kota Bima Tahun Pelajaran 2020/2021. Siswa setelah melakukan pembelajaran daring (online) berbasis Google Form, dapat belajar cara menggunakan dan 
meaplikasikan pembelajaran daring (online) khususnya mengaplikasikan Google Form. Pembelajaran daring (online) berbasis Google Form bisa dalam penelitian ini peneliti menggunakan Google Form untuk interaksi kelas, untuk daftar hadir, digunakan pada pelaksanaan tugas kelas, kuis, untuk membagikan dan pengisian angket, serta digunakan untuk pos tes.

\section{KESIMPULAN}

Adapun kesimpulan dari penelitian ini adalah 1) Penggunaan Google Form pada Pembelajaran Moda Daring dapat meningkatkan hasil Belajar Siswa Pada Mata Pelajaran Fisika materi teori relativitas khusus di SMAN 4 Kota Bima Kelas XII MIPA 1 Semester Ganjil Tahun Pelajaran 2020/2021; 2) Penggunaan Google Form pada Pembelajaran Moda Daring dapat meningkatkan kinerja guru Pada Mata Pelajaran Fisika.

Saran dan tindak lanjur dari penelitian ini adalah: 1) Kepada guru yang melaksanakan pembelajaran disarankan pembelajaran daring (online) berbasis Google Form pada mata Fisika sebagai upaya meningkatkan motivasi dan hasil belajar ditengah pandemi covid-19; 2) Kepada guru, disarankan untuk tetap memperhatikan rambu-rambu yang dimuat dalam Permendikbud Nomor 22 Tahun 2016 tentang standar proses disesuaikan dengan kondisi ditengah pandemi covid-19; 3) Kepada guru disarankan agar terus menggali dan mengembangkan pembelajaran daring (online)ditengah pandemi covid-19; 4) Kepada Kepala Sekolah disarankan untuk proaktif memotivasi guru agar secara kontinyu memperbaiki pembelajaran, memanfaatkan hasil peneltian guru guna peningkatan kualitas pembelajaran di sekolah khususnya ditengah pandemi covid-19; dan 5) Kepada instansi terkait, disaraankan untuk memberikan apresiasi yang tinggi dan kepada guru-guru yang telah melakukan inovasi pembelajaran. Apresiasi tersebut dapat berupa bantuan finansial untuk pengembangan inovasi pembelajaran guru lebih lanjut

\section{DAFTAR PUSTAKA}

Arikunto, Suharsimi. (2006). Prosedur Penelitian Suatu Pendekatan Praktik. Jakarta: Rineka Cipta.

Abidin. (2014). Desain Sistem Pembelajaran dalam Konteks Kurikulum 2013. Bandung: Refika Aditama.

Aqib, Zainal, et.al. (2009). Penelitian Tindakan Kelas. Bandung: CV Yrama Widya.

Ade, Sanjaya. (2011). Model-model Pembelajaran. Jakarta: Bumi Aksara.

A.M, Sardiman. (2007). Interaksi dan Motivasi Belajar Mengajar. Jakarta: Raja Grafindo Persada.

Aminah, N., Amami, S., Wahyuni, I., \& Rosita, C. D. (2021). Pemanfaatan Teknologi Melalui Pelatihan Penggunaan Aplikasi Google Site bagi Guru MGMP Matematika SMP Kabupaten Cirebon. Bima Abdi: Jurnal Pengabdian Masyarakat, 1(1), 23-29.

Dimyati dan Mudjiono. (2006). Belajar dan Pembelajaran. Jakarta: PT Rineke Cipta.

Erman Suherman, dkk. (2003). Strategi Pembelajaran Fisika Kontemporer. Bandung: UPI. 
Hamalik, Oemar. (2008). Perencanaan Pengajaran Berdasarkan Pendekatan Sistem.Jakarta: Bumi Aksara.

Hamzah B. Uno. (2011). Teori Motivasi dan Pengukurannya: Analisis di Bidang Pendidikan. Jakarta: Bumi aksara.

Hurlock, Elizabeth B. (1980). Psikologi Perkembangan: Suatu Pendekatan Sepanjang Rentang Kehidupan. Jakarta : Gramedia.

Kusumah, Wijaya dan Dwitagama, Dedi. (2009). Mengenal Penelitian Tindakan Kelas. Jakarta: PT. Indeks Permata Puri Media.

Kusuma, Wijaya. (2011). Penelitian Tindakan Kelas. Jakarta: PT Indeks.

Kemendikbud. (2016). Permendikbud Nomor 22 Tahun 2016 Tentang Standar Proses Pendidikan Dan Menengah. Jakarta: Kemendikbud.

Khotimah, N. K., Ashar, M. U., \& Nurhidayah, N. (2021). Penerapan Metode Diskusi Berbasis E-Learning dengan Penggunaan Aplikasi Edmodo, Zoom Cloud Meeting dan Quizizz untuk Meningkatkan Hasil Belajar Mahasiswa Materi Sistem Pencernaan pada Program Studi Keperawatan UIN Alauddin Makassar. Jurnal Pendidikan dan Pembelajaran Indonesia (JPPI), 1(1), 61-71.

Mulyatiningsih, E. (2011). Metode Penelitian Terapan Bidang Pendidikan. Yogyakarta: Alfabeta.

Latjuba Sofyana dan Abdul Rozaq. (2019). Penelitian berjudul Pembelajaran Daring Kombinasi Berbasis Whatsapp Pada Kelas Karyawan Prodi Teknik Informatika Universitas PGRI Madiun Jurnal Nasional Pendidikan Teknik Informatika. 8. 1, 81-86.

Padmono. (2010). Kelebihan Kekurangan Manfaat dan Penerapan PTK Seri PTK 15. [Online].Tersedia:http//m.kompasiana.com/post/edukasi/2010/10/09/Kelebihankekurangan-manfaat-dan-penerapan-PTK-seri-PTK-15/.[12 Maret 2013].

Sabran, \& Sabara, E. (2019). Keefektifan Google Classroom sebagai media pembelajaran. Penelitian, 122.

Slameto. (2010). Belajar dan faktor-faktor yang Mempengaruhinya. Jakarta: PT. Rineka Cipta.

Soedjadi. (2000). Kiat Pendidikan Fisika di Indonesia. Jakarta: Direktorat Jendral Pendidikan Tinggi Departemen Pendidikan Nasional.

Sudjana, Nana. (2009). Penilaian Hasil Proses Belajar Mengajar. Bandung: PT. Remaja Rosdakarya.

Sugihartono, dkk, (2007). Psikologi Pendidikan. Yogyakarta: UNY Pers.

Syarifuddin, S., Nugroho, P. B., Fadhli, M., Murtalib, M., Mutmainah, M., Muchlis, M., ... \& Hadi, A. M. (2021). Sosialisasi Aplikasi Pembelajaran Jarak Jauh dan Pengembangan Bahan Ajar bagi Dosen, Guru, dan Mahasiswa di Era Pandemi Covid-19. Bima Abdi: Jurnal Pengabdian Masyarakat, 1(1), 30-36.

Syarifuddin, S., Basri, H., Ilham, M., \& Fauziah, A. F. (2021). Efektifitas Pembelajaran Daring Mahasiswa Pendidikan Matematika ditengah Pandemi Covid-19. JagoMIPA: Jurnal Pendidikan Matematika dan IPA, 1(1), 1-8. 